Lingua Rima: Jurnal Pendidikan Program Studi Bahasa dan Sastra Indonesia

Vol. 9 No. 1 Juli 2020

\title{
EFEKTIFITAS MEDIA SOSIAL DALAM PENINGKATAN KETERAMPILAN MENULIS CERITA PENDEK
}

\author{
Hamdah Siti Hamsanah Fitriani ${ }^{1}$, Winda Dwi Hudhana ${ }^{2}$, Dhipa Erlangga Sanyoto ${ }^{3}$ \\ Universitas Muhammadiyah Tangerang \\ vitrianivit@gmail.com ${ }^{1}$ \\ $\frac{\text { windhana89@gmail.com }}{2}$
}

\begin{abstract}
ABSTRAK
Keterampilan menulis puisi dianggap sebagai keterampilan paling sulit. Oleh karena, pengarang harus memadaptkan bahasa dalam menulis puisi. Media sosial dapat digunakan sebagai media pembelajaran menulis puisi. Melalui media sosial, siswa dapat meningkatkan imajinasi dan inovasinya dalam mencipatakan puisi. Penelitian ini bertujuan untuk mengetahui efektivitas media sosial dalam meningkatkan keterampilan menulis puisi siswa siswa kelas X SMA Muhammadiyah 4 Kota Tangerang. Penelitian ini merupakan penelitian kualitatif dengan metode deskriptif analisis. Penelitian ini digunakan pada siswa kelas X SMAN Muhammadiyah 4 Kota Tangerang. Teknik pengumpulan data menggunakan teknik tes dan angket. Hasil penelitian yaitu rata-rata hasil pretest menulis puisi di SMA Muhammadiyah 4 Kota Tangerang melalui media sosial yaitu 69,3 dan postets 77,6. Hasil perhitungan angket guru yaitu 92\% dan siswa $88 \%$ maka dikategorikan sangat efektif.
\end{abstract}

Kata Kunci : Media Sosial, Menulis Puisi

\section{A. PENDAHULUAN}

Media sosial semakin menjamur dalam dunia maya dengan kecanggihan dan keunggulan yang ditonjolkan untuk menarik minat para pengguna media sosial. Para ahli informatika berlomba-lomba untuk membuat media sosial dengan keunggulan masing-masing, agar media sosial yang mereka ciptakan memiliki daya tarik dan populer. Beberapa media sosial populer misalnya friendster, facebook, twitter, instagram, dan sebagainya. Media-media sosial tersebut digunakan untuk berinteraksi dengan orang lain melalui dunia internet. Melalui media sosial seseorang dapat mengekspresikan imajinasi dan kreatifitasnya mengenai perasaan atau keinginannya.

Penggunaan media sosial berdampak baik bahkan buruk bagi seseorang. Media sosial sebagai tempat berinteraksi dengan seseorang tanpa harus bertatapmuka merupakan tujuan utama 
Lingua Rima: Jurnal Pendidikan Program Studi Bahasa dan Sastra Indonesia

Vol. 9 No. 1 Juli 2020

media sosial. Selain itu, media sosial digunakan sebagai media hiburan, sebagai media berekspresi, sebagai media promosi bisnis, dan lain sebagainya. Namun, dampak buruk penggunaan media sosial apabila seseorang menggunakan media sosial terlalu berlebihan sehingga lalai waktu. Dampak buruk lain yaitu dapat merubah orang menjadi anti-sosial, terjadi penipuan, bahkan penculikan. Maka, penggunaan media sosial harus sesuai batasan atau jangan berlebihan. Para penggunaan media sosial juga harus waspada dengan orang yang baru dikenal karena orang asing dapat dengan bebas melakukan tindak kejahatan.

Terkait dengan bahasa dan sastra Indonesia, media sosial merupakan media yang dapat digunakan oleh seseorang untuk mengungkapkan ekspresi dan imajinasi dalam bentuk tulisan dalam media sosial misalnya dalam menulis 'status'. Media sosial dapat dijadikan media pembelajaran dalam pembelajaran bahasa dan sastra Indonesia. Media sosial dapat digunakan siswa dalam mengekspresikan imajinasi ataupun kreatifitas menulis sebuah karya sastra melalui 'status' di media sosial. Siswa dapat bebas berimajinasi dalam menuliskan sebuah karya sastra berupa puisi yang dapat dipublikasikan dalam media sosial.

Kemampuan menulis puisi siswa kelas X SMA Muhammadiyah 4 Kota Tangerang masih rendah berdasarkan hasil observasi. Para siswa merasa kesulitan dalam menulis puisi berkaitan dengan pencarian ide, mengungkapkan gagasan, pemilihan diksi, dan lainnya. Para siswa juga kesulitan dalam mempublikasikan puisi yang telah ditulis. Selain itu, para siswa juga merasa tidak percaya diri dengan hasil puisi yang telah ditulis.

Media sosial sangat tepat digunakan sebagai media alternatif pembelajaran menulis puisi. Media sosial dapat mempublikasikan puisi siswa tidak terbatas ruang karena media sosial dapat dibaca oleh siapapun dan kapanpun. Media sosial sebagai media inspirasi siswa dalam memperoleh ide untuk menulis puisi. Media sosial yang digunakan merupakan media sosial populer misalnya facebook, twitter dan instagram yang digunakan oleh para sastrawan terkenal.

Oleh karena, para sastrawan terkenal sering membagikan puisi melalui media sosial. Oleh karena itu, penelitian ini bertujuan untuk mengetahui efektivitas media sosial dalam meningkatkan keterampilan menulis puisi siswa siswa kelas X SMA Muhammadiyah 4 Kota Tangerang.

\section{B. KAJIAN PUSTAKA}

Puisi merupakan bentuk sastra yang diciptakan dengan memilih dan memadatkan bahasa (Waluyo, 2010:2). Puisi diciptakan oleh seseorang dengan memilih bahasa yang bersifat indah dan memadatkan bahasa untuk mendapatkan makna yang mendalam. Puisi terbentuk atas tema 
Lingua Rima: Jurnal Pendidikan Program Studi Bahasa dan Sastra Indonesia

Vol. 9 No. 1 Juli 2020

makna, rasa, nada, dan amanat atau tujuan atau maksud (Tarigan, 2015:9). Puisi digunakan oleh seseorang untuk mengekspresikan ide dan gagasannya.

Keterampilan menulis puisi bertujuan untuk mengomunikasikan ide atau gagasan dan pengalaman hidup yang dimiliki kepada orang lain melalui tulisan-tulisan. Keterampilan menulis dapat dimiliki dan dimaksimalkan siswa melalui pembiasaan, pelatihan dan bimbingan yang intensif di sekolah. Pembelajaran menulis puisi selain untuk melatih menulis anak, juga dapat meningkatkan keterampilan berbahasa anak (Salamah, 2017:43-44).

Seseorang yang menyukai puisi biasanya tidak sebatas hanya menikmati puisi, namun akan mengapresiasi puisi. Maka, seseorang yang telah memiliki pengalaman apresiasi terhadap karya sastra maka ia kemudian berusaha untuk memproduksi karya sastra (Sundusiah dan Rahma, 2015:95). Seseorang dalam menulis puisi cenderung menulis berdasarkan pengalaman apresiasi puisi.

Kegiatan ekspresi tulis puisi dianggap sebagai salah satu kegiatan tersulit dalam bersastra. Kegiatan ini membutuhkan kepekaan batin dan keluwesan dalam menghasilkan kalimat atau kata-kata puitis yang terpilih. Kegiatan ini membutuhkan perenungan dan waktu yang cukup lama dalam menghasilkan karya sastra, terutama bagi penulis pemula. Kegiatan menulis puisi membutuhkan kreativitas memilih kata-kata yang tepat (Sundusiah dan Rahma, 2015:95)..

Pembelajaran menulis puisi dapat dilakukan secara efektif apabila guru dapat menerapkan strategi pembelajaran yang inovatif. Maka, siswa dapat lebih aktif, kreatif, dan imajinatif dalam menghasilkan puisi. Ada enam langkah melakukan strategi pembelajaran menulis puisi; antara lain (1) pemilihan objek yang diinginkan atau disenangi, (2) imajinasikan objek tersebut, (3) kreasikan imajinasimu dengan kata-kata, (4) ringkas dan kembangkan kata menjadi larik, (5) padukandan olah larik-larik menjadi bait-bait puisi, dan (6) publikasikan puisimu (Sutikno, 2016:226).

Peranan media sosial dalam keterampilan menulis puisi sebagai media mengekspresikan gagasannya berupa puisi. Media sosial dapat digunakan sebagai media publikasi puisi tanpa membutuhkan biaya dan tidak terbatas oleh ruang dan waktu. Penggunaan media sosial dalam pembelajaran menulis cerita pendek dibagi menjadi beberapa fase berikut:

Tabel 1. Fase Penggunaan Media Sosial dalam Keterampilan Menulis Cerita Pendek

\begin{tabular}{|c|l|l|}
\hline Fase & \multicolumn{1}{|c|}{ Kegiatan Guru } & \multicolumn{1}{c|}{ Kegiatan Siswa } \\
\hline Fase 1 penyampaian & Menyampaikan tujuan & Mendengarkan guru \\
\hline
\end{tabular}


Lingua Rima: Jurnal Pendidikan Program Studi Bahasa dan Sastra Indonesia Vol. 9 No. 1 Juli 2020

\begin{tabular}{|l|l|l|}
\hline $\begin{array}{l}\text { tujuan dan motivasi } \\
\text { siswa }\end{array}$ & $\begin{array}{l}\text { pembelajaran yang akan dicapai } \\
\text { dalam pembelajaran menulis } \\
\text { puisi menggunakan media sosial }\end{array}$ & $\begin{array}{l}\text { menjelaskan tujuan dan } \\
\text { motivasi belajar }\end{array}$ \\
\hline $\begin{array}{l}\text { Fase 2 penyajian } \\
\text { informasi }\end{array}$ & $\begin{array}{l}\text { Menyampaikan informasi terkait } \\
\text { dengan puisi dan media sosial } \\
\text { sebagai sumber inspirasi }\end{array}$ & $\begin{array}{l}\text { Mendengarkan penjelasan guru } \\
\text { berkait dengan puisi dan media } \\
\text { sosial }\end{array}$ \\
\hline $\begin{array}{l}\text { Fase 3 membimbing } \\
\text { siswa dalam }\end{array}$ & $\begin{array}{l}\text { Membimbing siswa yang } \\
\text { merasa kesulitan dalam } \\
\text { sosial }\end{array}$ & $\begin{array}{l}\text { Membaca status puisi yang } \\
\text { terdapat pada media sosial dan } \\
\text { mengunakiptakan puisi }\end{array}$ \\
\hline $\begin{array}{l}\text { Fase } 4 \text { evaluasi } \\
\text { menciptakan puisi }\end{array}$ & $\begin{array}{l}\text { Mengevaluasi puisi yang } \\
\text { diciptakan oleh siswa }\end{array}$ & $\begin{array}{l}\text { Memperhatikan guru dalam } \\
\text { evaluasi }\end{array}$ \\
\hline $\begin{array}{l}\text { Fase 5 memberikan } \\
\text { penghargaan bagi puisi } \\
\text { terbaik }\end{array}$ & $\begin{array}{l}\text { Memberikan penghargaan } \\
\text { berkaitan dengan puisi terbaik }\end{array}$ & $\begin{array}{l}\text { Ikut serta dalam pemberian } \\
\text { penghargaan bagi puisi terbaik }\end{array}$ \\
\hline
\end{tabular}

\section{METODE PENELITIAN}

Penelitian ini merupakan penelitian kualitatif dengan metode deskriptif analisis. Penelitian ini digunakan pada siswa kelas X SMAN Muhammadiyah 4 Kota Tangerang. Teknik pengumpulan data menggunakan teknik tes dan angket. Rancangan penelitian menggunakan rancangan pretest-postest satu kelompok.

\section{Tabel 2. Rancangan Penelitian}

\begin{tabular}{|c|c|c|}
\hline Pretest & Perlakuan & Postets \\
\hline $\mathbf{O}_{1}$ & $\mathbf{X}$ & $\mathbf{O}_{2}$ \\
\hline
\end{tabular}

Arifin (dalam Nugroho dan Shodikin, 2018:26)

Keterangan:

$\mathrm{O}_{1}$ : Pretest

$\mathrm{X}$ : Perlakuan penerapan media sosial dalam keterampilan menulis puisi

$\mathrm{O}_{2}$ : Postest

Kriteria keefektifan dinilai melalui angkat siswa dan guru dengan rumus sebagai berikut: 
Lingua Rima: Jurnal Pendidikan Program Studi Bahasa dan Sastra Indonesia

Vol. 9 No. 1 Juli 2020

$$
\mathrm{Ve}=\frac{\mathrm{TS}}{\operatorname{Smax}} X 100 \%
$$

Ve $=$ Validasi Efektifitas

TS $=$ Total Skor

Smax $=$ Skor Maksimal

Tabel 1. Kriteria Efektifitas Media Video Scribe

\begin{tabular}{|c|c|}
\hline Kriteria & Kategori \\
\hline $81 \%-100 \%$ & Sangat Efektif \\
\hline $61 \%-80 \%$ & Efektif \\
\hline $41 \%-60 \%$ & Cukup Efektif \\
\hline $21 \%-40 \%$ & Kurang Efektif \\
\hline $0 \%-20 \%$ & Tidak Efektif \\
\hline
\end{tabular}

\section{HASIL PENELITIAN}

Pelaksanaan kegiatan belajar mengajar menulis puisi, tahap awal dilakukan preteset. Hasil belajar menulis puisi diperoleh rata-rata 65, terdapat 7 siswa yang tuntas KKM dan 23 siswa tidak tuntas KKM. KKM dalam pembelajaran bahasa Indonesia yaitu7,5. Tahap kedua dilakukan tahap penjelasan materi berakitan dengan puisi dan teknik menulis puisi. Tahap ketiga, guru memberikan posttest. Pada tahap ini guru menggunakan media sosial berupa facebook, twitter dan instagram dalam pembelajaran menulis puisi. Para siswa membuka media sosial tersebut pada akun para sastrawan. Siswa membaca 'status' puisi yang diposting oleh sastrawan dan dijadikan sebagai refrensi atau acuan dalam membuat puisi. Pertemuan dilakukan sebanyak tiga kali. Berikut ini tabel hasil pretest dan postest menulis puisi siswa melalui media sosial.

Tabel 2. Hasil Belajar Menulis Puisi Siswa Berbantu Media Sosial Kelas X SMA Muhammadiyah 4 Kota Tangerang

\begin{tabular}{|l|l|l|l|}
\hline No & \multicolumn{1}{|c|}{ Nama Siswa } & Pretest & Postest \\
\hline 1 & HSA & 60 & 70 \\
\hline 2 & SFR & 65 & 78 \\
\hline 3 & RWH & 75 & 80 \\
\hline 4 & ADL & 55 & 70 \\
\hline 5 & HTS & 73 & 78 \\
\hline 6 & JTL & 80 & 85 \\
\hline 7 & GFP & 68 & 76 \\
\hline 8 & NKH & 61 & 73 \\
\hline 9 & NSD & 70 & 80 \\
\hline 10 & AHK & 82 & 87 \\
\hline 11 & IIR & 62 & 70 \\
\hline
\end{tabular}


Lingua Rima: Jurnal Pendidikan Program Studi Bahasa dan Sastra Indonesia

Vol. 9 No. 1 Juli 2020

\begin{tabular}{|l|l|l|l|}
\hline 12 & RA & 73 & 78 \\
\hline 13 & MA & 71 & 76 \\
\hline 14 & AFG & 64 & 70 \\
\hline 15 & HKS & 80 & 86 \\
\hline 16 & MAD & 70 & 84 \\
\hline 17 & DK & 68 & 78 \\
\hline 18 & FMS & 60 & 72 \\
\hline 19 & NH & 78 & 83 \\
\hline 21 & PPS & 71 & 79 \\
\hline 22 & MSA & 65 & 76 \\
\hline 23 & MMS & 63 & 70 \\
\hline 24 & ES & 77 & 82 \\
\hline 25 & IAS & 68 & 78 \\
\hline 26 & DAA & 80 & 86 \\
\hline 27 & IMH & 71 & 80 \\
\hline 28 & PRA & 72 & 77 \\
\hline 29 & GAD & 50 & 70 \\
\hline 30 & GTK & 66 & 76 \\
\hline & Rata-Rata & 69,3 & 77,6 \\
\hline & Siswa yang tuntas & 7 & 22 \\
\hline & Siswa yang tidak tuntas & 23 & 8 \\
\hline
\end{tabular}

Efektifitas media sosial dalam pembelajaran menulis puisi diketahui melalui angket yang disebarkan kepada guru dan siswa. Angket tersebut merupakan tanggapan guru dan siswa yang dinilai berdasarkan beberapa aspek antara lain digambarkan pada tabel berikut:

Tabel 3. Angket Efektivitas Media Sosial dalam Pembelajaran Menulis Puisi oleh Guru

\begin{tabular}{|l|l|c|}
\hline No & \multicolumn{1}{|c|}{ Aspek yang Dinilai } & Skor \\
\hline 1 & $\begin{array}{l}\text { Saya merasa terbantu dengan adanya media sosial dalam } \\
\text { pembelajaran menulis puisi }\end{array}$ & 5 \\
\hline 2 & $\begin{array}{l}\text { Media sosial sangat praktif digunakan dalam pembelajaran } \\
\text { menulis puisi }\end{array}$ & 5 \\
\hline 3 & $\begin{array}{l}\text { Siswa menjadi aktif dengan adanya media sosial dalam } \\
\text { pembelajaran menulis puisi }\end{array}$ & 4 \\
\hline 4 & $\begin{array}{l}\text { Melalui media sosial saya dapat membangun interaksi } \\
\text { pengan siswa sesuai dengan materi pembelajaran menulis } \\
\text { puisi mudan dan }\end{array}$ & 5 \\
\hline 5 & $\begin{array}{l}\text { Pembelajaran menulis puisi menjadi mudah } \\
\text { menyenangkan menggunakan media sosial }\end{array}$ & $\mathbf{2 3}$ \\
\hline & Total skor & $\mathbf{9 2 \%}$ \\
\hline & Presentase skor \\
\hline
\end{tabular}


Lingua Rima: Jurnal Pendidikan Program Studi Bahasa dan Sastra Indonesia

Vol. 9 No. 1 Juli 2020

Berdasarkan tabel tersebut, penilaian mengenai media sosial mencapai $92 \%$ dengan kriteria "sangat efektif". Hasil yang dicapai terkait dengan efektifitas media sosial dalam pembelajaran menulis puisi yaitu mengenai kemudahan media sosial dalam pembelajaran menulis puisi, kepraktisan media sosial, keaktifan siswa dalam penggunaan media sosial, interaksi antara guru dan siswa dapat terbangun, dan media sosial menimbulkan kemudahan serta kesenangan dalam menulis puisi.

Tabel 4. Angket Efektivitas Media Sosial dalam Pembelajaran Menulis Puisi oleh Siswa

\begin{tabular}{|c|l|c|}
\hline No & \multicolumn{1}{|c|}{ Aspek yang Dinilai } & Rata-Rata Skor \\
\hline 1 & $\begin{array}{l}\text { Pembelajaran menulis puisi menjadi menarik dan } \\
\text { menyenangkan dengan media sosial }\end{array}$ & 5 \\
\hline 2 & Media sosial memudahkan siswa dalam menciptakan puisi & 5 \\
\hline 3 & $\begin{array}{l}\text { Media sosial dapat mempermudah siswa menyalurkan } \\
\text { gagasan }\end{array}$ & 4 \\
\hline 4 & Media sosial dapat membangkitkan imajinasi siswa & 4 \\
\hline 5 & $\begin{array}{l}\text { Penggunaan media sosial memotivasi siswa untuk menulis } \\
\text { puisi }\end{array}$ & 4 \\
\hline & Total Skor & $\mathbf{2 2}$ \\
\hline & Presentase & $\mathbf{8 8 \%}$ \\
\hline
\end{tabular}

Berdasarkan tabel tersebut, rata-rata perolehan efektifitas media sosial oleh siswa mencapai 88\% atau menduduki kategori "sangat efektif". Penggunaan media sosial erkait dengan angket siswa yaitu ketertarikan terhadap media sosial dalam pembelajaran menulis puisi, kemudahan siswa dalam membuat puisi, kemudahan dalam siswa menyalurkan gagasan dalam membuat puisi, media sosial dapat membangkitkan imajinasi siswa dalam mencipatakan puisi, dan media sosial dapat memotivasi siswa dalam menulis puisi.

Media sosial digunakan dalam pembelajaran menulis puisi dikategorikan efektif menurut angket guru dan siswa. Media sosial dapat digunakan siswa sebagai acuan dalam menciptakan puisi. Kelebihan media sosial dalam pembelajaran menulis puisi yaitu: 1) media sosial dapat memberikan inovasi baru bagi siswa dalam menciptakan puisi, 2) media sosial dapat memberikan inspirasi dan meningkatkan daya imajinasi siswa dalam menciptakan puisi, 3) media sosial dapat mengaktifkan siswa untuk terus membuat puisi, 4) media sosial dapat meningkatkan daya kreatifitas siswa dalam menciptakan puisi, 5) pembelajaran menulis puisi menjadi lebih menarik. 
Lingua Rima: Jurnal Pendidikan Program Studi Bahasa dan Sastra Indonesia

Vol. 9 No. 1 Juli 2020

\section{E. SIMPULAN}

Rata-rata Hasil pretest menulis puisi di SMA Muhammadiyah 4 Kota Tangerang melalui media sosial yaitu 69,3 dan postets 77,6. Hasil perhitungan angket guru yaitu 92\% dan siswa 88\% maka dikategorikan sangat efektif. Kelebihan media sosial dalam pembelajaran menulis puisi yaitu: 1) media sosial dapat memberikan inovasi baru bagi siswa dalam menciptakan puisi, 2) media sosial dapat memberikan inspirasi dan meningkatkan daya imajinasi siswa dalam menciptakan puisi, 3) media sosial dapat mengaktifkan siswa untuk terus membuat puisi, 4) media sosial dapat meningkatkan daya kreatifitas siswa dalam menciptakan puisi, 5) pembelajaran menulis puisi menjadi lebih menarik.

\section{F. DAFTAR PUSTAKA}

Nugroho, Setiaji dan Ali Shodikin, 2018. Keefektifan Pembelajaran Student Teams Achievement division (STAD) Berbantu Komik pada Siswa SD. Jurnal Matematika dan Pendidikan Matematika. Vol 3 No 12018 Hal 22-32 http://journal.unipdu.ac.id:8080/index.php/jmpm/article/view/1067/778

Salamah, Evi Rizqi. 2017. Media Cerita Bergambar untuk Meningkatkan Keterampilan Menulis Puisi Anak. Jurnal Pedagogia. Vol 6 No 12017 Hal 43-53 http://ojs.umsida.ac.id/index.php/pedagogia/article/view/616/617

Sundusiah, Suci dan Rosita Rahma. 2015. Model Poetry Wrodgame dalam Pembelajaran Ekspresi Tulis Puisi Pada Pembelajaran Bahasa Indonesia Bagi Penutur Asing. Jurnal Penelitian Pendidikan. Vol 15 No 32015 Hal 43-53 https://ejournal.upi.edu/index.php/JER/article/view/1431/981

Sutikno. 2016. Pengembangan Model Sinektik pada Pembelajaran Menulis Puisi Berkonteks Multikultural dalam Pembentukan Karakter Siswa SMA. Jurnal Indonesian Language and Literature. Vol 1 No 22016 Hal http://www.syekhnurjati.ac.id/jurnal/index.php/jeill/article/view/225/958

Tarigan, Henry Guntur. 2015. Prinsip Dasar Sastra. Bandung: Penerbit Angkasa Waluyo, Herman J. 2010. Pengkajian dan Apresiasi Puisi. Salatiga: Widya Sari Press 